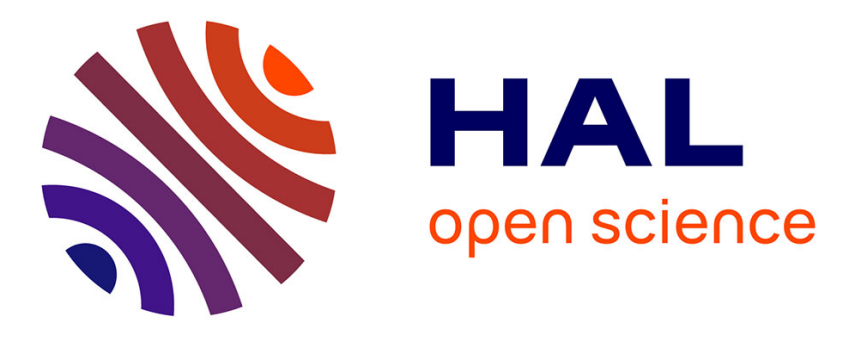

\title{
Preparation of nitrogen doped zinc oxide nanoparticles and thin films by colloidal route and low temperature nitridation process
}

Arnaud Valour, François Cheviré, Franck Tessier, Fabien Grasset, Benjamin Dierre, Tengfei Jiang, Eric Faulques, Laurent Cario, Stéphane Jobic

\section{To cite this version:}

Arnaud Valour, François Cheviré, Franck Tessier, Fabien Grasset, Benjamin Dierre, et al.. Preparation of nitrogen doped zinc oxide nanoparticles and thin films by colloidal route and low temperature nitridation process. Solid State Sciences, 2016, 54, pp.30-36. 10.1016/j.solidstatesciences.2015.12.009 . hal-01245031

\section{HAL Id: hal-01245031 \\ https://hal.science/hal-01245031}

Submitted on 16 Dec 2015

HAL is a multi-disciplinary open access archive for the deposit and dissemination of scientific research documents, whether they are published or not. The documents may come from teaching and research institutions in France or abroad, or from public or private research centers.
L'archive ouverte pluridisciplinaire HAL, est destinée au dépôt et à la diffusion de documents scientifiques de niveau recherche, publiés ou non, émanant des établissements d'enseignement et de recherche français ou étrangers, des laboratoires publics ou privés. 


\title{
Preparation of nitrogen doped zinc oxide nanoparticles and thin films by colloidal route and low temperature nitridation process
}

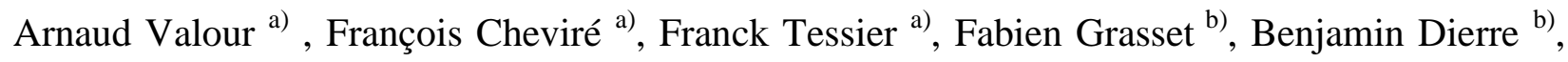
Tengfei Jiang ${ }^{\mathrm{c}}$, Eric Faulques ${ }^{\mathrm{c}}$, Laurent Cario ${ }^{\mathrm{c}}$, Stéphane Jobic ${ }^{\mathrm{c})}$

a) Institut des Sciences Chimiques de Rennes (UMR CNRS 6226), Université de Rennes 1, 263 avenue du Général Leclerc, 35042 Rennes cedex, France

${ }^{b)}$ Laboratory for Innovative Key Materials and Structures - National Institute of Material Science (UMI 3629 CNRS/Saint Gobain) - Tsukuba, Japon

c) Institut des Matériaux Jean Rouxel, Université de Nantes, CNRS, 2 rue de la Houssinière, 44322 Nantes cedex 3, France

\begin{abstract}
:
Nitrogen doped zinc oxide $(\mathrm{ZnO})$ nanoparticles have been synthesized using a colloidal route and low temperature nitridation process. Based on these results, $200 \mathrm{~nm}$ thick transparent $\mathrm{ZnO}$ thin films have been prepared by dip-coating on $\mathrm{SiO}_{2}$ substrate from a $\mathrm{ZnO}$ colloidal solution. Zinc peroxide $\left(\mathrm{ZnO}_{2}\right)$ thin film was then obtained after the chemical conversion of a $\mathrm{ZnO}$ colloidal thin film by $\mathrm{H}_{2} \mathrm{O}_{2}$ solution. Finally, a nitrogen doped $\mathrm{ZnO}$ nanocrystalline thin film ( $\left.\mathrm{ZnO}: \mathrm{N}\right)$ was obtained by ammonolysis at $250^{\circ} \mathrm{C}$. All the films have been characterized by scanning electron microscopy, X-ray diffraction, X-Ray photoelectron spectroscopy and UV-Visible transmittance spectroscopy.
\end{abstract}

Keywords: Nitrogen doped $\mathrm{ZnO}$, thin films, dip-coating, nanoparticles 


\section{Introduction}

Zinc oxide $(\mathrm{ZnO})$ is a material of great interest exhibiting pigmental [1], photocatalytic [2], piezoelectric [3], antibacterial [4], or varistor [5] properties that have already been developed in many different fields of industry [6]. Still novel applications emerge in various domains but they often require the preliminary stabilization of a p-type $\mathrm{ZnO}$, which is more difficult to achieve than that of the unintentionally doped n-type $\mathrm{ZnO}$. In optoelectronics for instance, the high optical transparency of $\mathrm{ZnO}$ thin films coupled with their high electrical conductivity and their strong room temperature luminescence could indeed open up the door to great improvement of technologies such as flat panel displays [7], light emitting diodes [8] or lasers [9]. In a previous study, we have reported the stabilization of p-type nitrogen doped zinc oxide nanoparticles with metal vacancies up to $15-20 \%(\mathrm{ZnO}: \mathrm{N})$ obtained through the decomposition of zinc peroxide $\left(\mathrm{ZnO}_{2}\right)$ at low temperature under ammonia flow [10]. Moreover, we have recently demonstrated that the zinc vacancies segregate preferentially at the surface of the $\mathrm{ZnO}$ nanoparticles to form a pseudo core-shell structure built upon a stoichiometric zinc oxide core coated with a few angstroms thick Zn-free oxo-hydroxide shell [11]. These studies have to be extended for the realization of p-type $\mathrm{ZnO}$ thin films to achieve $\mathrm{n}-\mathrm{ZnO} / \mathrm{p}-\mathrm{ZnO}: \mathrm{N}$ homojonctions which would lead to various applications in optoelectronics.

In this work, we report on a simple colloidal approach to form $200 \mathrm{~nm}$ thick $\mathrm{ZnO}: \mathrm{N}$ thin films by reacting $\mathrm{ZnO}_{2}$ precursors with flowing ammonia at low temperature as illustrated on Figure 1. We will discuss on the synthesis of the $\mathrm{ZnO}, \mathrm{ZnO}_{2}$ and $\mathrm{ZnO}: \mathrm{N}$ nanoparticles as well as the formation of the corresponding high quality thin films. Their structural and optical properties were investigated by means of ultraviolet-visible (UV-Vis) spectroscopy, X-ray diffraction (XRD), X-ray photoelectron spectroscopy (XPS) and scanning electron microscopy (SEM). 


\section{Experimental section}

\subsection{Nanoparticles synthesis of $\mathrm{ZnO}, \mathrm{ZnO}_{2}$ and $\mathrm{ZnO}: \mathrm{N}$}

$\mathrm{ZnO}$ based nanoparticles and thin films were obtained from $\mathrm{ZnO}$ colloidal solution. This solution was prepared using similar route as published in references 12 and 13 . In practice, $4.39 \mathrm{~g}$ of $\mathrm{Zn}\left(\mathrm{CH}_{3} \mathrm{COO}\right)_{2}, 2 \mathrm{H}_{2} \mathrm{O}$ (Fluka, 99.5\%) were dissolved in $40 \mathrm{~mL}$ of 1-propanol (Acros, 99.9\%). After distillation of $9 \mathrm{~mL}$ of the as-obtained solution in a preheated $\left(125^{\circ} \mathrm{C}\right)$ oil bath of a rotary evaporator, $9 \mathrm{~mL}$ of tetramethylammonium hydroxide (TMAOH) in methanol (Alfa Aesar, $25 \%$ $\mathrm{w} / \mathrm{w}$ in methanol) were rapidly added in the still hot solution. This addition induced the formation of a turbid solution which immediately disappeared after a strong agitation, the mixture being transformed into a clear colloidal suspension. This solution was kept 24 hours under magnetic stirring before being precipitated with $80 \mathrm{~mL}$ of diethyl ether (Carlo Erba, 99.8\%). The white $\mathrm{ZnO}$ powders were separated by centrifugation (12000 rpm during $5 \mathrm{~min}$ ) and were dried with acetone to obtain $\mathrm{ZnO}$ nanoparticles.

The $\mathrm{ZnO}$ powders were then dispersed into $\mathrm{H}_{2} \mathrm{O}_{2} / \mathrm{H}_{2} \mathrm{O}$ mixture $(5 / 95 \mathrm{~mL})$ and were heated under reflux and stirring at $100^{\circ} \mathrm{C}$ during $6 \mathrm{~h}$ to form a yellowish $\mathrm{ZnO}_{2}$ powder. After centrifugation and drying steps (12 $000 \mathrm{rpm} / 10 \mathrm{~min}$ ), $300 \mathrm{mg}$ of the as-prepared products were treated under ammonia flux $\left(20 \mathrm{~L}^{-\mathrm{h}^{-1}}\right)$ at $250{ }^{\circ} \mathrm{C}$ during $30 \mathrm{~min}$ to form $\mathrm{ZnO}: \mathrm{N}$ powders with an orange / brown color.

\subsection{Elaboration of $\mathrm{ZnO}, \mathrm{ZnO}_{2}$ and $\mathrm{ZnO}: \mathrm{N}$ thin films}

$\mathrm{ZnO}$ thin films were deposited on $\mathrm{SiO}_{2}$ substrate by a dip-coating method at room temperature with a withdrawing speed around $200 \mathrm{~mm} / \mathrm{min}$ from a transparent $\mathrm{ZnO}$ colloidal solution obtained by dispersion of the $\mathrm{ZnO}$ nanoparticles in absolute ethanol (Prolabo, normapur). The 
$\mathrm{ZnO}$ concentration of the solution was determined to be $0.9 \mathrm{M}$ by inductively coupled plasma mass spectrometry (ICP-MS). The film was air dried in a chemical fume hood and annealed in air at $150^{\circ} \mathrm{C}$ for $15 \mathrm{~min}$. The $\mathrm{ZnO}$ thin film was then immersed into a $\mathrm{H}_{2} \mathrm{O}_{2}$ (Sigma Aldrich, $30 \%$ wt in $\left.\mathrm{H}_{2} \mathrm{O}\right)$ / distilled $\mathrm{H}_{2} \mathrm{O}$ mixture $(5 / 35 \mathrm{~mL}$ ) at room temperature under stirring for 2 hours to convert $\mathrm{ZnO}$ into $\mathrm{ZnO}_{2}$. Finally, the $\mathrm{ZnO}_{2}$ film was reacted under flowing ammonia $\left(20 \mathrm{~L}^{-1}{ }^{-1}\right)$ at $250^{\circ} \mathrm{C}$ for $30 \mathrm{~min}$ in order to obtain a slightly orange $\mathrm{ZnO}: \mathrm{N}$ thin film.

\subsection{Characterizations}

\subsubsection{Powders}

XRD powder patterns were recorded by using a PANalytical X'pert Pro diffractometer (Bragg Brentano geometry, $\mathrm{Cu} \mathrm{K} \alpha_{1}, \alpha_{2}(\lambda=1.5418 \AA)$ equipped with a PIXcel 1D detector). Data were collected in the $5-120^{\circ} 2 \theta$ range with an overall collection time of $2 \mathrm{~h}$. Data Collector and HighScore Plus software were used, respectively, for recording and analyzing the patterns. For each sample, the average crystallites sizes were estimated from the whole diffraction pattern $\left(5^{\circ}<2 \theta<120^{\circ}\right)$ using FullProf Suite software and based on the Scherrer equation [14]:

$t=\frac{\lambda}{\beta \cos \theta}$

with $t$ the average crystallite size and $\beta$ the integral width. Nitrogen and oxygen contents were determined with a LECO TC-600 Analyzer using the inert gas fusion method in which nitrogen and oxygen contents were measured by thermal conductivity and infrared analyses, respectively. Diffuse reflectance (DR) spectra were collected using a Varian Cary 100 Scan spectrometer equipped with a Varian WinUV software and the integrating sphere Labsphere (DRC-CA-30I). Experimental data were collected within the $250-800 \mathrm{~nm}$ range with a $1 \mathrm{~nm}$ step. The band-gap 
of the materials (Eg) were calculated using the Kubelka-Munk formalism [15]. Thermal stability of the $\mathrm{ZnO}_{2}$ was determined from thermogravimetric and differential thermal analyses (TGA/TDA) conducted in air at $2^{\circ} \mathrm{C} / \mathrm{min}$ and performed with a TA instruments SDT 2960. The overall accuracy of this instrument is expected to be within $\pm 2{ }^{\circ} \mathrm{C}$. Density measurements on $\mathrm{ZnO}: \mathrm{N}$ powders were carried out with a Micromeretics AccuPyc 1330. XPS analyses were performed on a Kratos Axis NOVA spectrometer. Spectra were collected using Al K monochromatic radiation $(\mathrm{hv}=1486.6 \mathrm{eV})$ on $\mathrm{a} \sim 300 \times 700 \mu \mathrm{m}$ area at a pass energy of $160 \mathrm{eV}$. All spectra were calibrated in energy using C $1 \mathrm{~s}=284.7 \mathrm{eV}$ as reference.

\subsubsection{Thin films}

XRD patterns were recorded by grazing incidence X-ray diffraction (GIXRD) in order to limit the substrate contribution using a Rigaku SMARTLAB apparatus equipped by D/TeX Ultra 250 detector and $\mathrm{Cu}$ radiation with $\Theta-\Theta$ configuration. Data were collected in the $10-60^{\circ} 2 \theta$ range with a step of 0.02 and a speed of $1 \%$ min. Transmittance UV-Vis spectra were collected using a Perkin Elmer Lambda 35 UV-Vis spectrometer in the $200-700 \mathrm{~nm}$ range with a $1 \mathrm{~nm}$ step. The film surface and cross-section observations (for thickness determination) were conducted using a JEOL 6301F scanning electron microscope.

\section{Results and discussion}

Several theoretical studies [16-18] have pointed out that both nitrogen doping and metal vacancies may stabilize shallow acceptors levels above the valence band in $\mathrm{ZnO}$, thus triggering the stabilization of a p-type conductivity. As reported in a recent work on the decomposition of $\mathrm{ZnO}_{2}$ to prepare $\mathrm{Zn}$-deficient $\mathrm{ZnO}$, the nanostructuration of $\mathrm{ZnO}$ appears to be essential to control the metal vacancies in $\mathrm{ZnO}$ particles [11]. Starting from a colloidal $\mathrm{ZnO}$ solution, we have 
modified the $\mathrm{ZnO}_{2}$ approach in order to have a better control of the nanostructuration of $\mathrm{ZnO}: \mathrm{N}$ nanoparticles and thin films, i.e. a better control of the particle size and the size distribution. It is interesting to note that preliminary investigations on the reactivity towards ammonia at $300^{\circ} \mathrm{C}$ of $\mathrm{ZnO}$ nanoparticles issued from the colloidal process was very poor. Slightly brown materials were obtained due to the insertion of very low amount of nitrogen. This prompts us to take benefit of the strong reactivity of $\mathrm{ZnO}_{2}$ towards ammonia at low temperature to prepared $\mathrm{N}: \mathrm{ZnO}$ films.

\subsection{ZnO:N nanoparticles}

The XRD pattern of powders (Fig. 2) prepared from colloidal route indicates the formation of $\mathrm{ZnO}$ nanoparticles with the wurtzite structure-type (JCPDS file 01-079-0206). Interestingly, no acetate derivative zinc hydroxide double salts were observed as impurities at low angle [19]. After $\mathrm{H}_{2} \mathrm{O}_{2}$ treatment, the diffraction peaks corresponding to $\mathrm{ZnO}_{2}$ are well indexed in the pyrite structure (JCPDS file 01-077-2414, $\mathrm{a}=4.871 \AA$ ), which confirms the conversion of $\mathrm{ZnO}$ into $\mathrm{ZnO}_{2}$. At last, the XRD pattern of the nitrided $\mathrm{ZnO}: \mathrm{N}$ powder presents similar diffraction peaks to $\mathrm{ZnO}$ powder with a higher crystallization state. Calculations of the average crystallites sizes were performed on the different samples and are listed in Table 1. $\mathrm{ZnO}$ and $\mathrm{ZnO}_{2}$ nanoparticles display similar average crystallites sizes around 4-5 nm. The growth of the average size of $\mathrm{ZnO}: \mathrm{N}$ nanoparticles (up to $45 \mathrm{~nm}$ ) during the low temperature nitridation $\left(250^{\circ} \mathrm{C}\right.$ ) is attributed to the locally increase of the reaction temperature due to the highly exothermic decomposition of $\mathrm{ZnO}_{2}$.

The thermal behavior of $\mathrm{ZnO}_{2}$ powder was studied by TGA/DTA analyses (Fig. 3). The TGA curve shows three different weight losses. The first one, below $200{ }^{\circ} \mathrm{C}$, is due to the elimination of adsorbed water at the surface. $\mathrm{ZnO}_{2}$ shows an intensive weight loss $(14.5 \%)$ around $200^{\circ} \mathrm{C}$ 
corresponding to the decomposition of $\mathrm{ZnO}_{2}$ into $\mathrm{ZnO}$ with metal vacancies $\left(\mathrm{Zn}_{1-\mathrm{x}} \mathrm{O}\right)$. This phenomenon is well known to be highly exothermic [20,21], as the DTA curve also shows in Figure 3 with an important exothermic signal at $200^{\circ} \mathrm{C}$. The last weight loss $(3.9 \%)$ from $200^{\circ} \mathrm{C}$ to $400^{\circ} \mathrm{C}$ illustrates the progressive conversion from $\mathrm{Zn}_{1-\mathrm{x}} \mathrm{O}$ to a stoichiometric $\mathrm{ZnO}$ with temperatures identical to those reported in previous works [10, 11]. Indeed, density measurement, carried out on the $\mathrm{ZnO}: \mathrm{N}$ powder obtained at $250^{\circ} \mathrm{C}$, gives an experimental value of 5.1 , that is lower than the theoretical density of $\mathrm{ZnO}(\mathrm{d}=5.6)$.

Diffuse reflectance analyses performed on $\mathrm{ZnO}$ reveal a typical absorption band around $390 \mathrm{~nm}$ corresponding to the $2 \mathrm{p}(\mathrm{O})-4 \mathrm{~s}(\mathrm{Zn})$ electronic transition (Fig. 4), from which a band-gap value $\mathrm{Eg}=3.24 \mathrm{eV}$ is extracted (Table 1). The conversion of $\mathrm{ZnO}$ into $\mathrm{ZnO}_{2}$ goes along with a shift of the absorption threshold $340 \mathrm{~nm}(\mathrm{Eg}=3.79 \mathrm{eV})$. Finally, after the nitridation step, the $\mathrm{ZnO}: \mathrm{N}$ spectrum displays two diffuse reflectance bands: one around $400 \mathrm{~nm}$ corresponding to the $2 \mathrm{p}(\mathrm{O})$ - 4s (Zn) transition with a band gap of $\mathrm{Eg}=3.09 \mathrm{eV}$ and a broad signal between 450-650 $\mathrm{nm}$ attributed to the nitrogen doping. Due to the difference in electronegativity between oxygen and nitrogen, i.e. 3.5 and 3.0 respectively, nitrogen doping in $\mathrm{ZnO}$ may induce the insertion of localized nitrogen states above $2 \mathrm{p}(\mathrm{O})$ states at the top of valence band. Moreover, the slight red of the absorption threshold from $390 \mathrm{eV}$ in $\mathrm{ZnO}$ to $400 \mathrm{eV}$ in $\mathrm{ZnO}: \mathrm{N}$ may be attributed to particles growth effect due to heating at $250^{\circ} \mathrm{C}$.

Oxygen and nitrogen contents were determined for the $\mathrm{ZnO}, \mathrm{ZnO}_{2}$ and $\mathrm{ZnO}: \mathrm{N}$ nanoparticles. They are listed in Table 1. $\mathrm{ZnO}$ sample presents a high oxygen content compared to the theory (19.6 wt \%) which can be partially due to adsorbed water or acetate molecules at the surface of the $\mathrm{ZnO}$ nanoparticles [22-24]. Such large oxygen content in metal oxides nanoparticles is not surprising as the nanoscale will strongly affect the stoichiometry of the nanoparticles compared to 
the corresponding bulk material. For such small particles $(\sim 5 \mathrm{~nm})$, the contribution of the surface over the "bulk" of the particle is quite large and can lead indeed to large oxygen/metal non stoichiometry due to passivation/hydroxylation of surface metal sites [11]. As shown in Figure 5, $\mathrm{N} 1 \mathrm{~s}$ XPS analysis on the as-prepared $\mathrm{ZnO}$ nanoparticles reveals the presence of residual nitrogen atoms $(0.4 \mathrm{wt} \%)$ that likely originates from TMAOH used during the synthesis, the N1s peak at $402.9 \mathrm{eV}$ being ascribed to $\left(\mathrm{CH}_{3}\right)_{4} \mathrm{~N}^{+}$species [25]. After conversion, $\mathrm{ZnO}_{2}$ nanoparticles present an oxygen content close to the theory $(32.8 \mathrm{wt} \%)$ and a very low nitrogen content that indicates the good purity of the materials with elimination of the nitrogen containing impurities. At last, the oxygen content measured in $\mathrm{ZnO}: \mathrm{N}$ sample around $21 \mathrm{wt} \%$ suggests the presence of zinc vacancies in the material in good agreement with the DTA/TGA and density analyses as well as with previously reported works $[10,18]$. The increase of the nitrogen content in ZnO:N sample at 0.5 wt $\%$ confirms the effective insertion of nitrogen in the compound along with the slight orange/brown coloration and UV-Vis results [23,24]. Moreover, XPS spectrum of the nitrided sample exhibits a N1s peak at $399.6 \mathrm{eV}$ that could be attributed to $\mathrm{NH}_{\mathrm{x}}$ species at the surface of the nanoparticules [26].

\subsection{Thin films}

We have studied the transposition of the results obtained on powders to the elaboration of thin films by dip-coating from the same starting colloidal solution. GIXRD patterns of the different thin films are shown in Figure 6. The different diffraction peaks for the $\mathrm{ZnO}$ film, in the $10-60^{\circ}$ $2 \theta$ range, can be indexed in the wurtzite structure type (JCPDS file 01-079-0206). The broad peak around $15-25^{\circ}$ comes the $\mathrm{SiO}_{2}$ substrate. After $\mathrm{H}_{2} \mathrm{O}_{2}$ treatment, the film presents two main peaks around 32 and $37^{\circ}(111)$ and (200), respectively and a smaller one around $53^{\circ}((220)$ peak). These peaks unambiguously correspond to $\mathrm{ZnO}_{2}$ with the pyrite structure and confirm that $\mathrm{ZnO}$ 
films were successfully converted into zinc peroxide. These results are also in good agreement with those obtained for powders (Fig. 2). XRD pattern of the $\mathrm{ZnO}: \mathrm{N}$ film appears similar to that of $\mathrm{ZnO}$ film with a lower crystallization state, confirming the decomposition of the $\mathrm{ZnO}_{2}$ film into $\mathrm{ZnO}: \mathrm{N}$ under ammonolysis conditions. The broad diffraction peaks of the different samples suggest the nanoscale size of the particles within the thin films. The lower apparent crystallization of the $\mathrm{ZnO}: \mathrm{N}$ film compared to the corresponding powder sample comes from different amounts of $\mathrm{ZnO}_{2}$ precursor used in powders and thin films experiments. While both powder and thin film samples have been reacted under ammonia in the same conditions $\left(250^{\circ} \mathrm{C}-\right.$ $30 \mathrm{~min}-$ ammonia flow $\left.=20 \mathrm{~L} \cdot \mathrm{h}^{-1}\right)$, the amount of $\mathrm{ZnO}_{2}$ in the case of thin films $(\sim 1.5 \mathrm{mg}$, film size $\left.\sim 25 \times 50 \times 25.10^{-5} \mathrm{~mm}\right)$ was about 200 times lower than for powder samples $(\sim 300 \mathrm{mg})$. As the decomposition of $\mathrm{ZnO}_{2}$ around $200^{\circ} \mathrm{C}$ leading to the zinc deficient $\mathrm{Zn}_{1-\mathrm{x}} \mathrm{O}$ is very exothermic, the much larger quantity of precursor used in the case of powders would lead to a significant increase of the local temperature during the nitridation thus causing the observed growth of the nanocrystallites.

SEM images of the thin films show that the $\mathrm{ZnO}$ film consists of a dense and homogeneous film with a thickness around $200 \mathrm{~nm}$ (Fig. 7A). The SEM images are in agreement with the broad profile of the diffraction peaks suggesting the small size of the $\mathrm{ZnO}$ particles. $\mathrm{ZnO}$ nanoparticles of less than $10 \mathrm{~nm}$ size agglomerate to form, after annealing at $150^{\circ} \mathrm{C}$, aggregates with a size around $50 \mathrm{~nm}$. As illustrated in Figure 7B, after conversion in $\mathrm{H}_{2} \mathrm{O}_{2}$ solution, the surface of the film appears less dense with an increase of the particles sizes. Moreover, Figure 7B shows an increase of the thickness of the $\mathrm{ZnO}_{2}$ film up to $250 \mathrm{~nm}$. The increase of the thickness is concomitant with the structural change of the film from wurtzite-type $\mathrm{ZnO}$ into pyrite-type $\mathrm{ZnO}_{2}$. This suggests that the film can tolerate a phase conversion without destruction. In the same way, 
the thickness of the $\mathrm{ZnO}: \mathrm{N}$ nanocrystalline thin film decreases around $210 \mathrm{~nm}$ after nitridation at $250^{\circ} \mathrm{C}$ under $\mathrm{NH}_{3}$, and a slight densification of the layer is observed (Fig. 7C). This is in agreement with the thermal decomposition of $\mathrm{ZnO}_{2}$ into $\mathrm{ZnO}: \mathrm{N}$ and support the formation of a $\mathrm{ZnO}: \mathrm{N}$ thin film with metal vacancies by analogy with the results obtained on powders. It is worth pointing out that the highly exothermic decomposition of $\mathrm{ZnO}_{2}$ which is associated with an important in-situ release of oxygen gas, do not degrade the quality of the $\mathrm{ZnO}: \mathrm{N}$ film during the ammonolysis step at $250^{\circ} \mathrm{C}$.

UV-Vis transmittance analyses carried out on the thin films (Fig. 8) reveal an absorption band in the UV region for the $\mathrm{ZnO}$ transparent film around $370 \mathrm{~nm}$. After chemical conversion in $\mathrm{H}_{2} \mathrm{O}_{2}$ solution, the $\mathrm{ZnO}_{2}$ thin film remains transparent and the adsorption is blue shifted to the UV region $(<300 \mathrm{~nm})$. Finally, the slightly orange $\mathrm{ZnO}: \mathrm{N}$ thin film presents a $\mathrm{ZnO}$ characteristic absorption edge around $370 \mathrm{~nm}$ and a broad absorption in the visible between 400 and $500 \mathrm{~nm}$ attributed to the insertion of nitrogen in the material during the decomposition of $\mathrm{ZnO}_{2}$ under $\mathrm{NH}_{3}$. We note an important difference about absorption values for $\mathrm{ZnO}$ and more especially for $\mathrm{ZnO}_{2}$ between powders and thin films samples. All the transmittance curves present a transmittance higher than $80 \%$ and fringes above the absorption limit, due to the interference of the reflection of the light on transparent substrate and film surfaces. This phenomenon depends on the refractive indexes and the thickness of the film [27]. The higher the thickness, the stronger the oscillations. Figure 9 shows the XPS spectra of $\mathrm{N} \mathrm{1s}$ for both $\mathrm{ZnO}$ and $\mathrm{ZnO}: \mathrm{N}$ thin films. The $\mathrm{N}$ 1s spectrum of $\mathrm{ZnO}$ film dip-coated from the colloidal solution and annealed at $150^{\circ} \mathrm{C}$ indicates some residual TMAOH species (peak at $402.8 \mathrm{eV}$ [25]) as observed for the powder sample. In addition to the orange coloration observed for the $\mathrm{ZnO}: \mathrm{N}$ thin film, the $\mathrm{N} 1 \mathrm{~s}$ peak at 
$399.2 \mathrm{eV}$ confirms the nitrogen insertion in the film after nitridation as it can be attributed to $\mathrm{NH}_{\mathrm{x}}$ species [26].

\section{Conclusion}

In summary, $\mathrm{ZnO}: \mathrm{N}$ powders with zinc vacancies were synthesized following a colloidal route and nitridation process at low temperature. These results were successfully transposed to the realization of $\mathrm{ZnO}: \mathrm{N}$ nanocrystalline thin films by dip-coating from a colloidal solution on $\mathrm{SiO}_{2}$ substrates. $\mathrm{ZnO}$ film was converted into $\mathrm{ZnO}_{2}$ using a $\mathrm{H}_{2} \mathrm{O}_{2}$ solution in order to obtain, after a nitridation step at $250^{\circ} \mathrm{C}$ under $\mathrm{NH}_{3}$, a slightly orange $\mathrm{ZnO}: \mathrm{N}$ transparent thin film. The resulting film presented a dense and homogeneous surface with a regular thickness around $200 \mathrm{~nm}$. The supposed presence of $\mathrm{Zn}$ vacancies coupled with nitrogen insertion in the $\mathrm{ZnO}$ thin film is the key to access stable p-type conductivity for future $\mathrm{p}-\mathrm{n} \mathrm{ZnO}$ homojunction.

\section{Acknowledgments}

We are grateful to M. Nakatsu (MANA-NIMS), F. Gouttefangeas, L. Joanny, (CMEBA-Rennes), B. Lefeuvre (ISCR) and Jonathan Hamon (IMN) for their help in XRD, SEM, ICP-MS and XPS studies respectively. This work was supported by the French Research Agency (ANR) under the grant ANR-13-BS08-0010 devoted to the stabilization of p-type $\mathrm{ZnO}$ with $\mathrm{ZnO}_{2}$ as precursor.

\section{References}

[1] N. Kiomarsipour, R. Shoja Razavi, K. Ghani, M. Kioumarsipour, Appl. Surf. Sci. 270 (2013) 33-38.

[2] G. Patrinoiu, J.M. Calderón-Moreno, D. C. Culita, R. Birjega, R. Ene, O. Carp, Solid State Sci. 23 (2013) 58-64.

[3] Z.L.Wang, J. Song, Science 312 (2006) 242-246.

[4] C. Karunakaran, V. Rajeswari, P. Gomathisankar, Solid State Sci. 13 (2011) 923- 928. 
[5] T. K. Gupta, J. Am. Ceram. Soc. 73(7) (1990) 1817-1840.

[6] Ü. Özgür, Ya. I. Alivov, C. Liu, A. Teke, M. A. Reshchikov, S. Dogan, V. Avrutin, S.-J. Cho, H. Morkoç, J. Appl. Phy. 98(4) (2005) 041301.

[7] B.S. Chua, S. Xu, Y.P. Ren, Q.J. Cheng, K. Ostrikov, J. Alloys Compd. 485 (2009) 379-384.

[8] S.H. Park, S.H. Kim, S.W. Han, Nanotechnol. 18 (2007) 055608.

[9] L. Znaidi, G.J.A.A. Soler Illia, S. Benyahia, C. Sanchez, A.V. Kanaev, Thin Solid Films 428 (2003) 257-262.

[10] B. Chavillon, L. Cario, A. Renaud, F. Tessier, F. Cheviré, M. Boujtita, Y. Pellegrin, E. Blart, A. Smeigh, L. Hammarström, F. Odobel, S. Jobic, J. Amer. Chem. Soc. 134 (2012) 464-470.

[11] A. Renaud, L Cario, X. Rocquefelte, P. Deniard, C. Payen, E. Gautron, E. Faulques, F. Cheviré, F. Tessier, S. Jobic, Scientific Reports 5 (2015) 12914.

[12] F. Grasset, L. Spanhel, S. Ababou-Girard, Superlat. Microstruct. 38 (2005) 300-307.

[13] F. Grasset, G. Starukh, L. Spanhel, S. Ababou-Girard, D. Su, A. Klein, Adv. Mater. 17(3) (2005) 294-297.

[14] P. Scherrer, Nach. Gesell, Gott. Wissens, Math. Phys. 1-2 (1918) 96-100.

[15] D. Kubelka, L. Munk, Z. Tech. Phys. 12 (1931) 593-601.

[16] J. G. Reynolds, C. L. Reynolds Jr., A. Mohanta, J. F. Muth, J. E. Rowe, H. O. Everitt, D. E. Aspnes, Appl. Phy. Lett. 102 (2013) 152114.

[17] A Boonchun, W. R. L. Lambrecht, Phys. Status Solidi B 250 (2013) 2091-2101.

[18] J. Bang, Y. Sun, D. West, B. Meyer, S. Zhang, J. Mater. Chem. C 3 (2015) 339-344.

[19] F. Grasset, O. Lavastre, C. Baudet, T. Sasaki, H. Haneda, J. Colloid Interface Sci. 317 (2008) 493-500.

[20] K.A. Kim, J.R. Cha, M.S. Gong, J.G. Kim, Bull. Korean Chem. Soc. 35 (2014) 431-435.

[21] N. Uekawa, N. Mochizuki, J. Kajiwara, F. Mori, Y.J. Wu and K. Kakegawa, Phys. Chem. 5 (2003) 929-934.

[22] S. Sakohara, M. Ishida, M. A. Anderson, J. Phys. Chem. B 102 (1998) 10169-10175.

[23] D. Li, H. Haneda, J. Photochem. Photobiol. A Chem. 155 (2003) 171-178.

[24] D Li, H. Haneda, Chemosphere 54(8) (2004) 1099-1110. 
[25] M. Chigane, M. Ishikawa, J. Chem. Soc., Faraday Trans. 94 (1998) 3665-3670.

[26] N. Herring, L. Panchakarla, M. Samy El-Shall, Langmuir 30 (2014) 2230-2240.

[27] R. Swanepoel, J. Phys. E: Sci. Instrum. 16 (1983) 1214-1222. 


\section{Figures and Tables}

Table 1: Oxygen/nitrogen determination, average crystallites sizes and band gaps of $\mathrm{ZnO} / \mathrm{ZnO}_{2} / \mathrm{ZnO}: \mathrm{N}$ powders.

Figure 1: Schematic approach for the synthesis of the $\mathrm{Zn}_{1-\mathrm{x}} \mathrm{O}: \mathrm{N}$ thin films

Figure 2: $\mathrm{XRD}$ patterns of $\mathrm{ZnO} / \mathrm{ZnO}_{2} / \mathrm{ZnO}: \mathrm{N}$ powders (*sample holder).

Figure 3: DTA/TGA curve of $\mathrm{ZnO}_{2}$.

Figure 4: Diffuse reflectance spectra of $\mathrm{ZnO} / \mathrm{ZnO}_{2} / \mathrm{ZnO}: \mathrm{N}$.

Figure 5: $\mathrm{N}$ 1s XPS spectra of $\mathrm{ZnO}$ and $\mathrm{ZnO}: \mathrm{N}$ powders.

Figure 6: $\mathrm{XRD}$ patterns of $\mathrm{ZnO}, \mathrm{ZnO}_{2}$ and $\mathrm{ZnO}: \mathrm{N}$ thin films on $\mathrm{SiO}_{2}$ substrate.

Figure 7: SEM images of thin films: (A) $\mathrm{ZnO}$ (B) $\mathrm{ZnO}_{2}(\mathrm{C}) \mathrm{Zn}_{1-\mathrm{x}} \mathrm{O}: \mathrm{N}$. On the left: side view of the cross-section, on the right: top view of the films.

Figure 8: UV-Visible transmittance spectra of $\mathrm{ZnO}, \mathrm{ZnO}_{2}$ and $\mathrm{ZnO}: \mathrm{N}$ thin films on $\mathrm{SiO}_{2}$ substrate.

Figure 9: $\mathrm{N}$ 1s XPS spectra of $\mathrm{ZnO}$ and $\mathrm{ZnO}: \mathrm{N}$ thin films. 


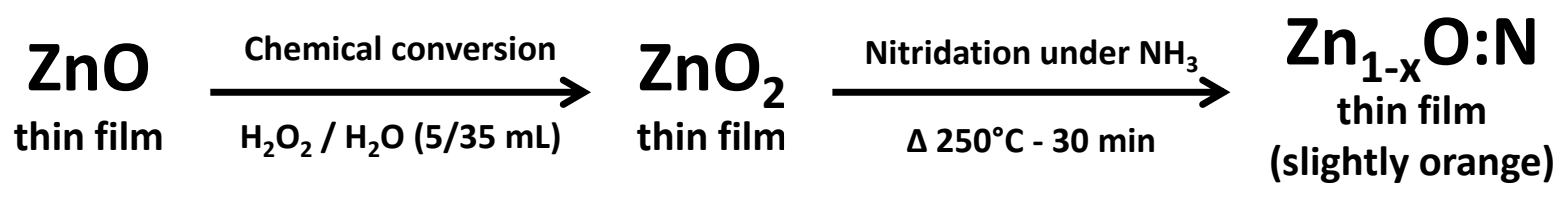

Figure 1: Schematic approach for the synthesis of the $\mathrm{Zn}_{1-\mathrm{x}} \mathrm{O}: \mathrm{N}$ thin films 


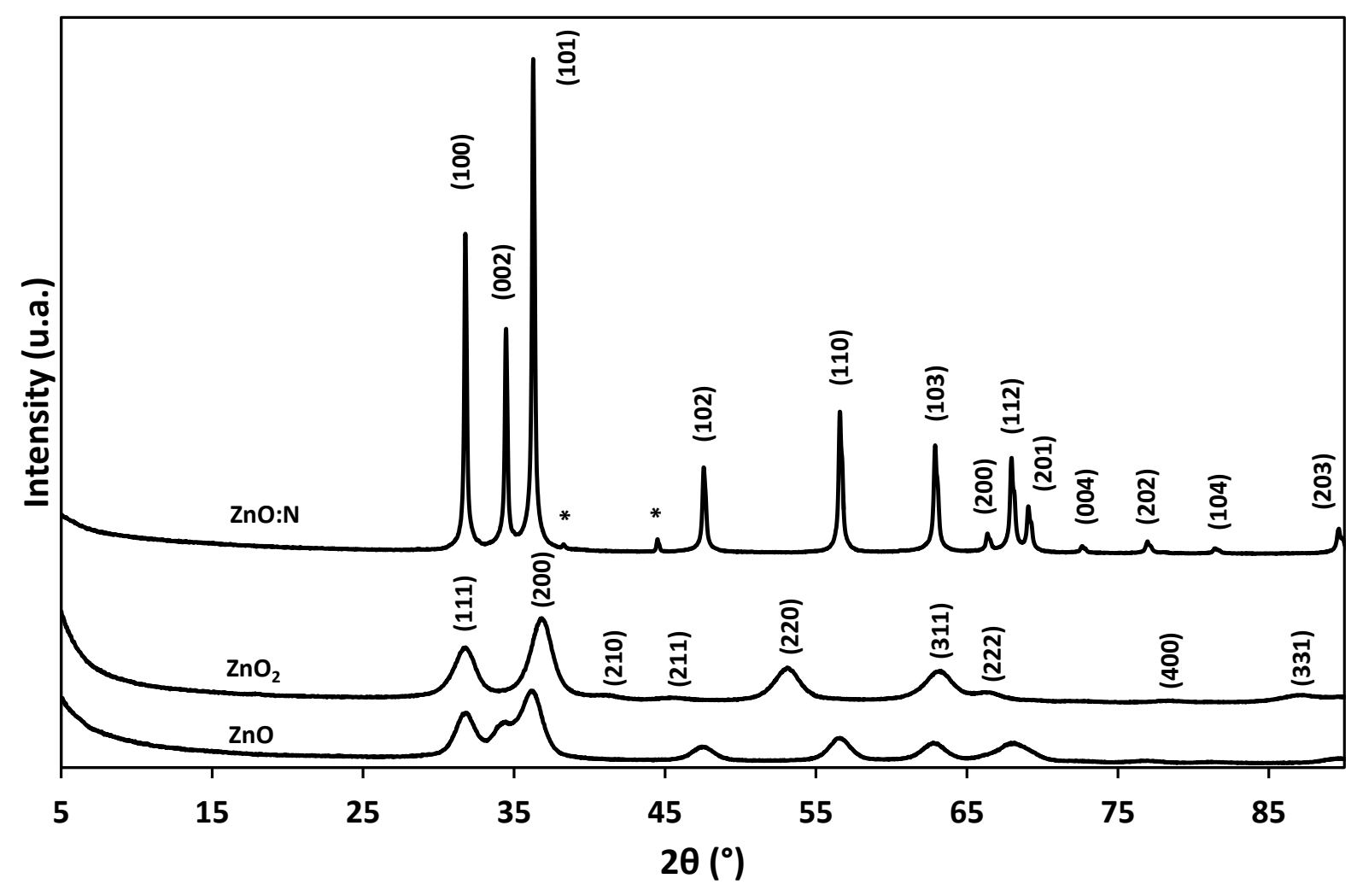

Figure 2: $\mathrm{XRD}$ patterns of $\mathrm{ZnO} / \mathrm{ZnO}_{2} / \mathrm{ZnO}: \mathrm{N}$ powders ( ${ }^{*}$ sample holder). 


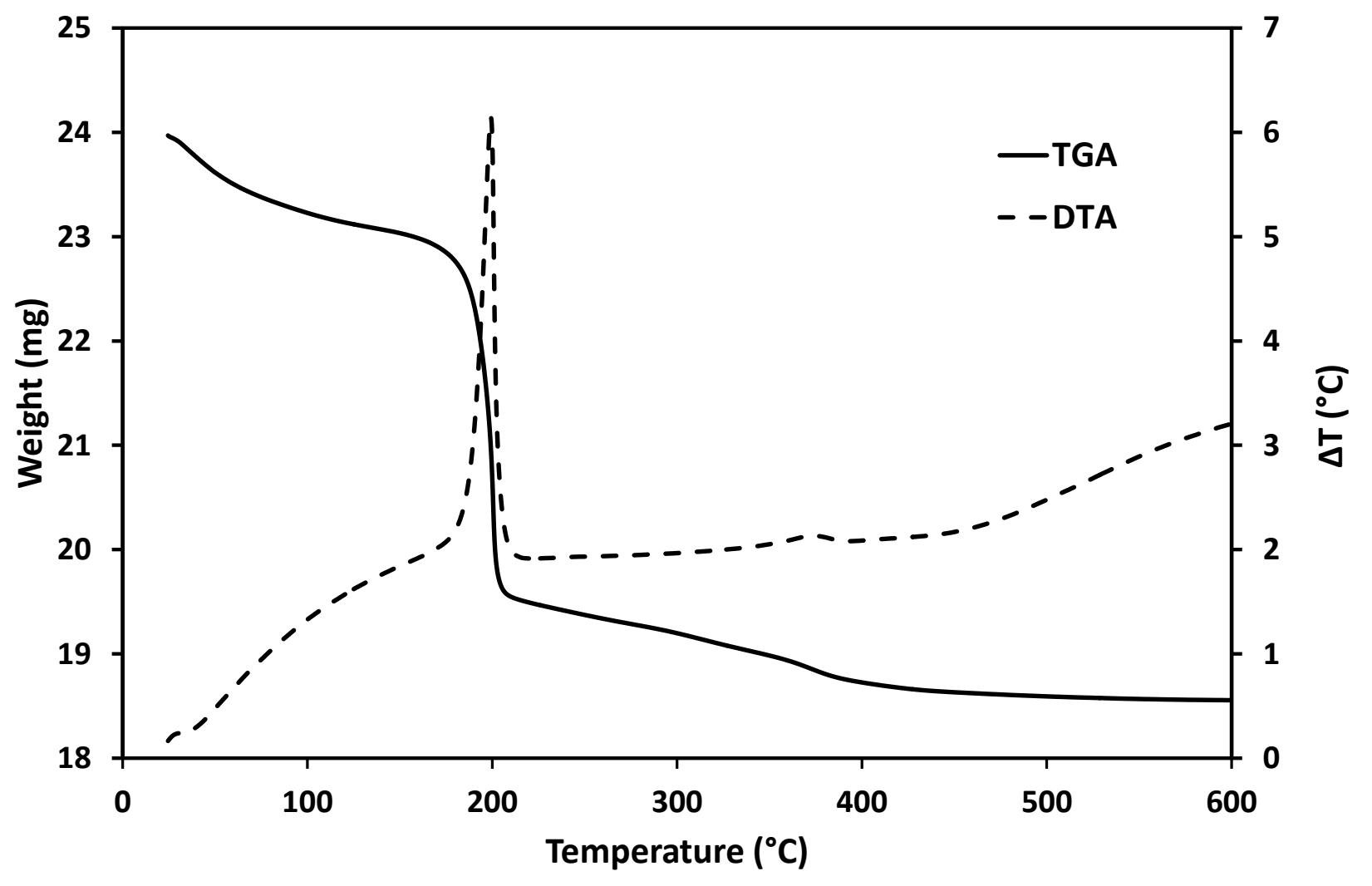

Figure 3: DTA/TGA curve of $\mathrm{ZnO}_{2}$. 


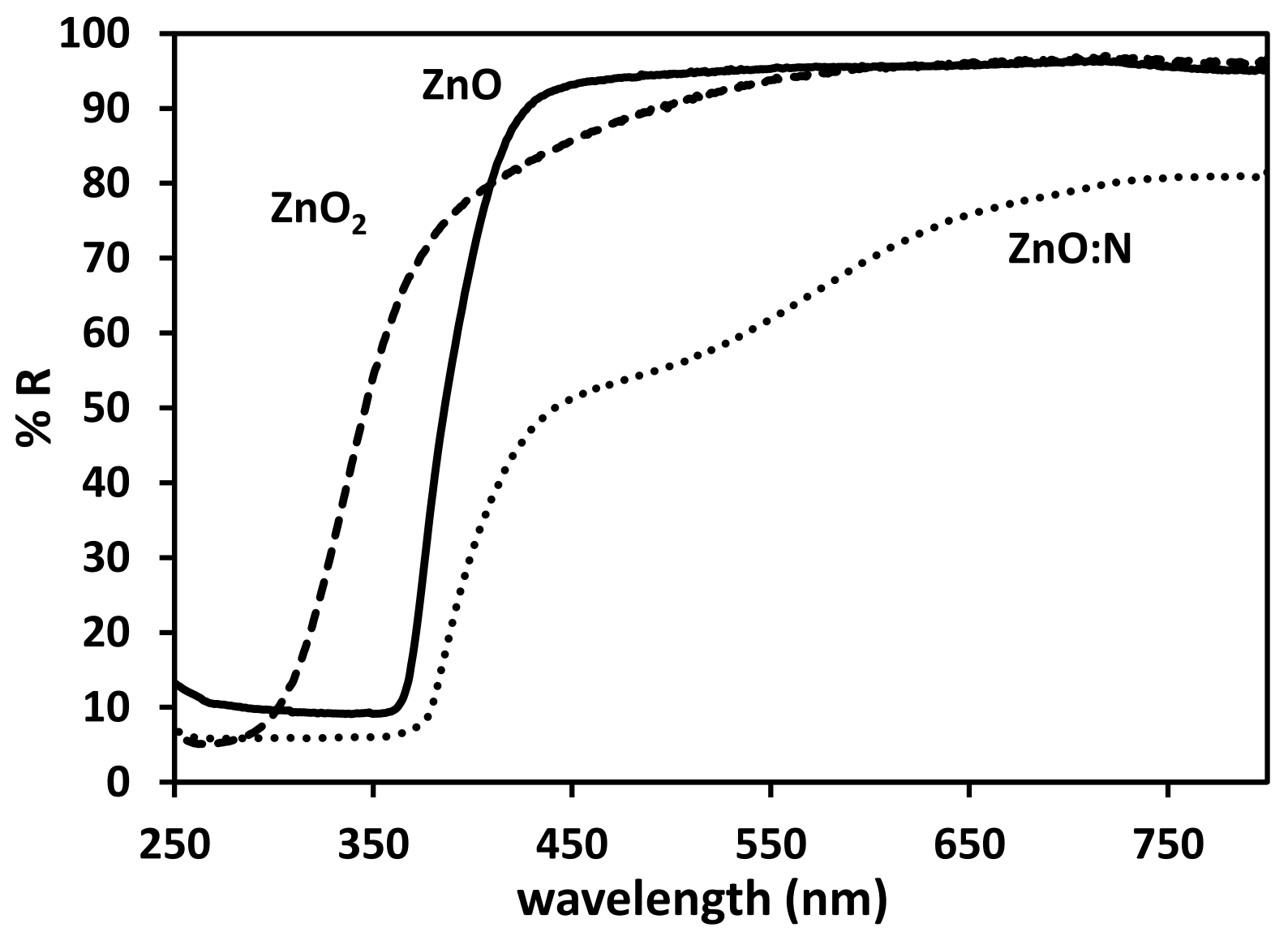

Figure 4: Diffuse reflectance spectra of $\mathrm{ZnO} / \mathrm{ZnO}_{2} / \mathrm{ZnO}: \mathrm{N}$. 


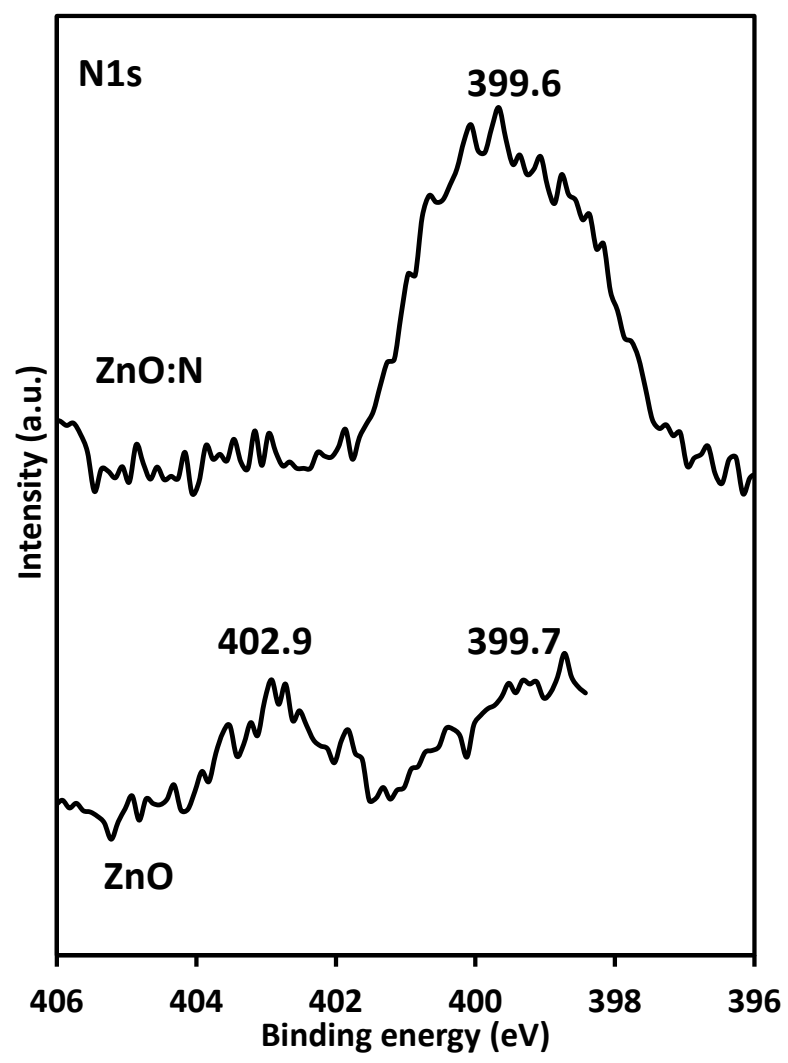

Figure 5: $\mathrm{N}$ 1s XPS spectra of $\mathrm{ZnO}$ and $\mathrm{ZnO}: \mathrm{N}$ powders. 


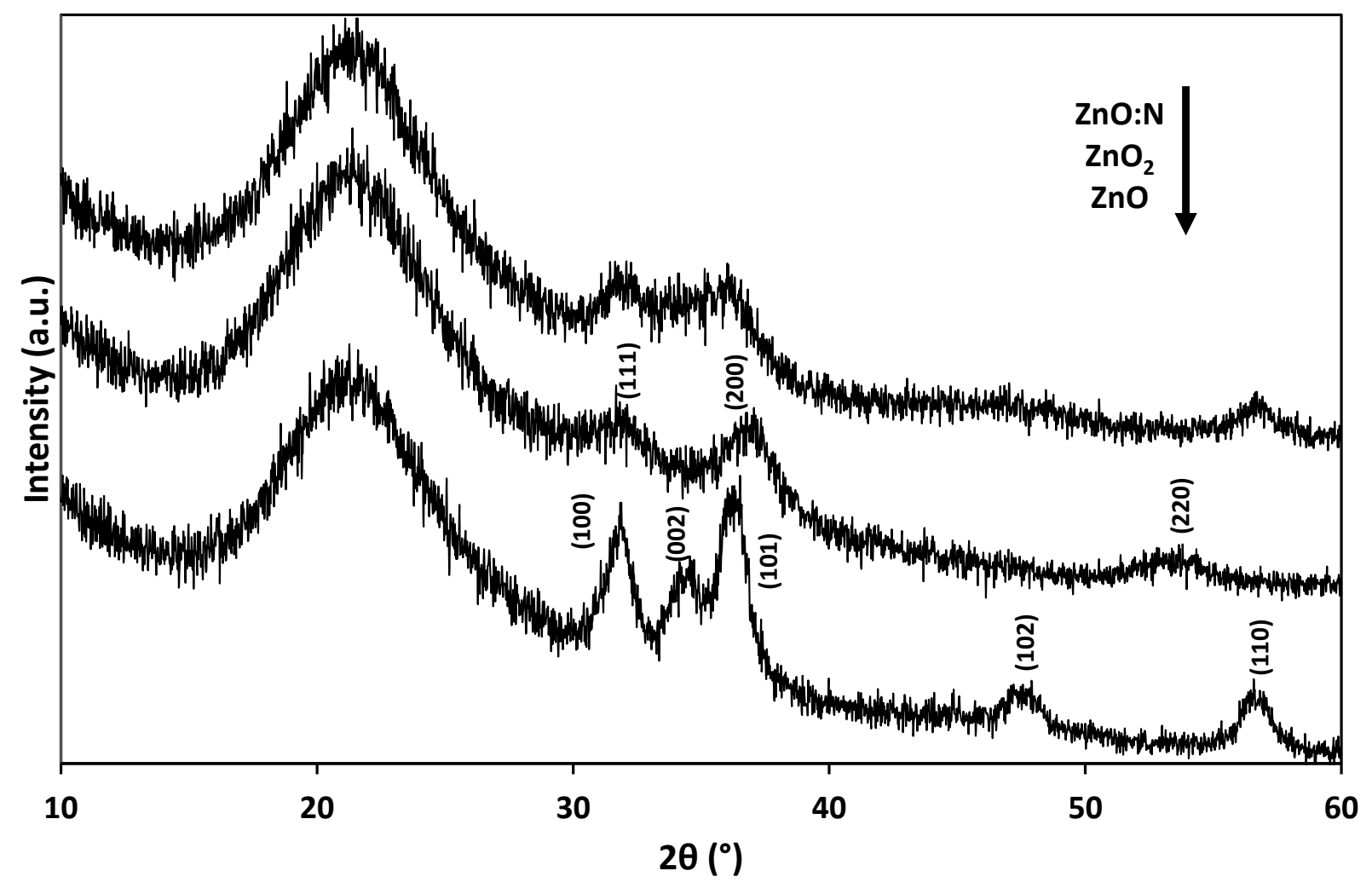

Fig.6: $\mathrm{XRD}$ patterns of $\mathrm{ZnO}, \mathrm{ZnO}_{2}$ and $\mathrm{ZnO}: \mathrm{N}$ thin films on $\mathrm{SiO}_{2}$ substrate. 

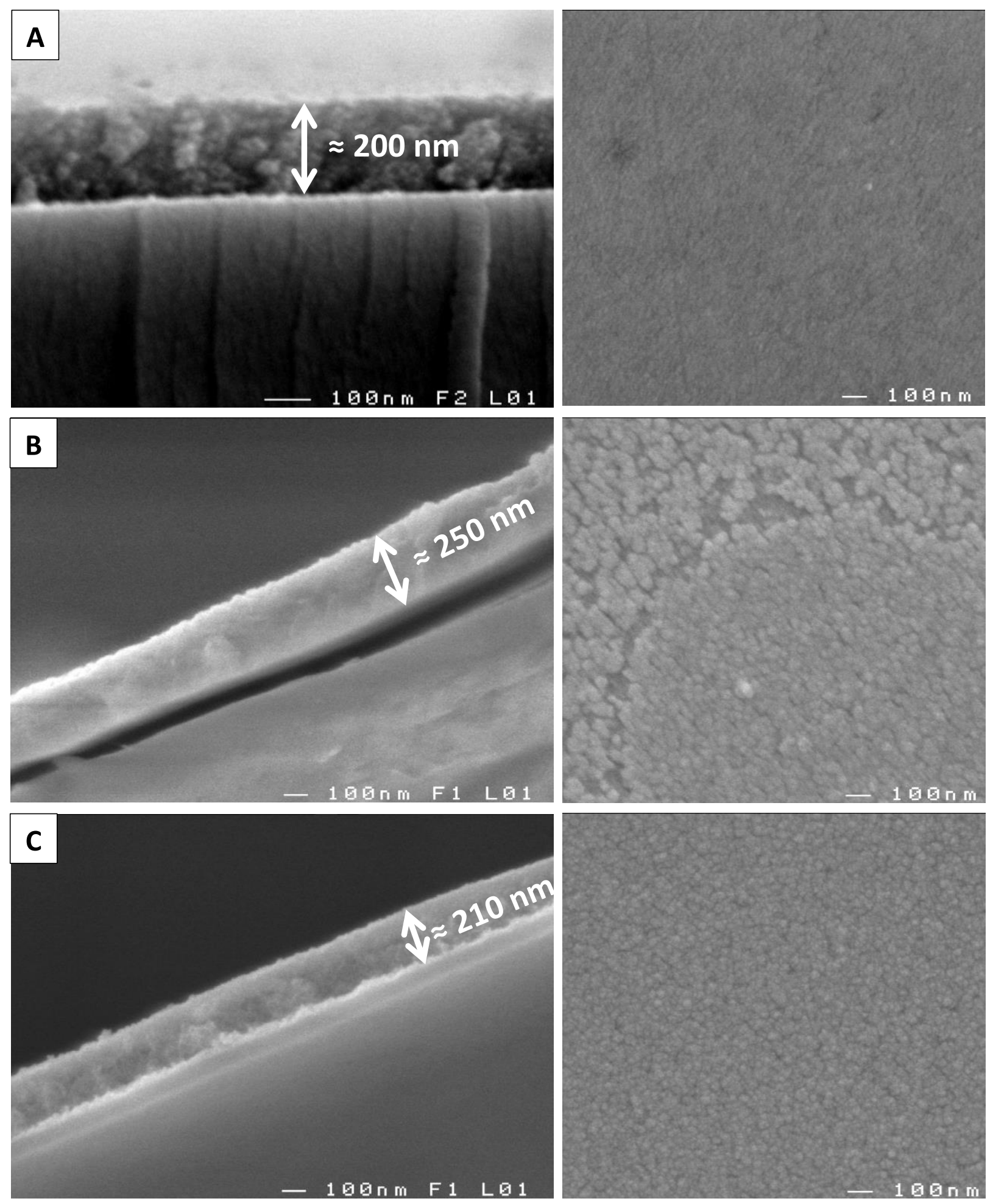

Figure 7: SEM images of thin films: (A) $\mathrm{ZnO}$ (B) $\mathrm{ZnO}_{2}$ (C) $\mathrm{Zn1-xO}$ :N. On the left: side view of the cross-section, on the right: top view of the films. 


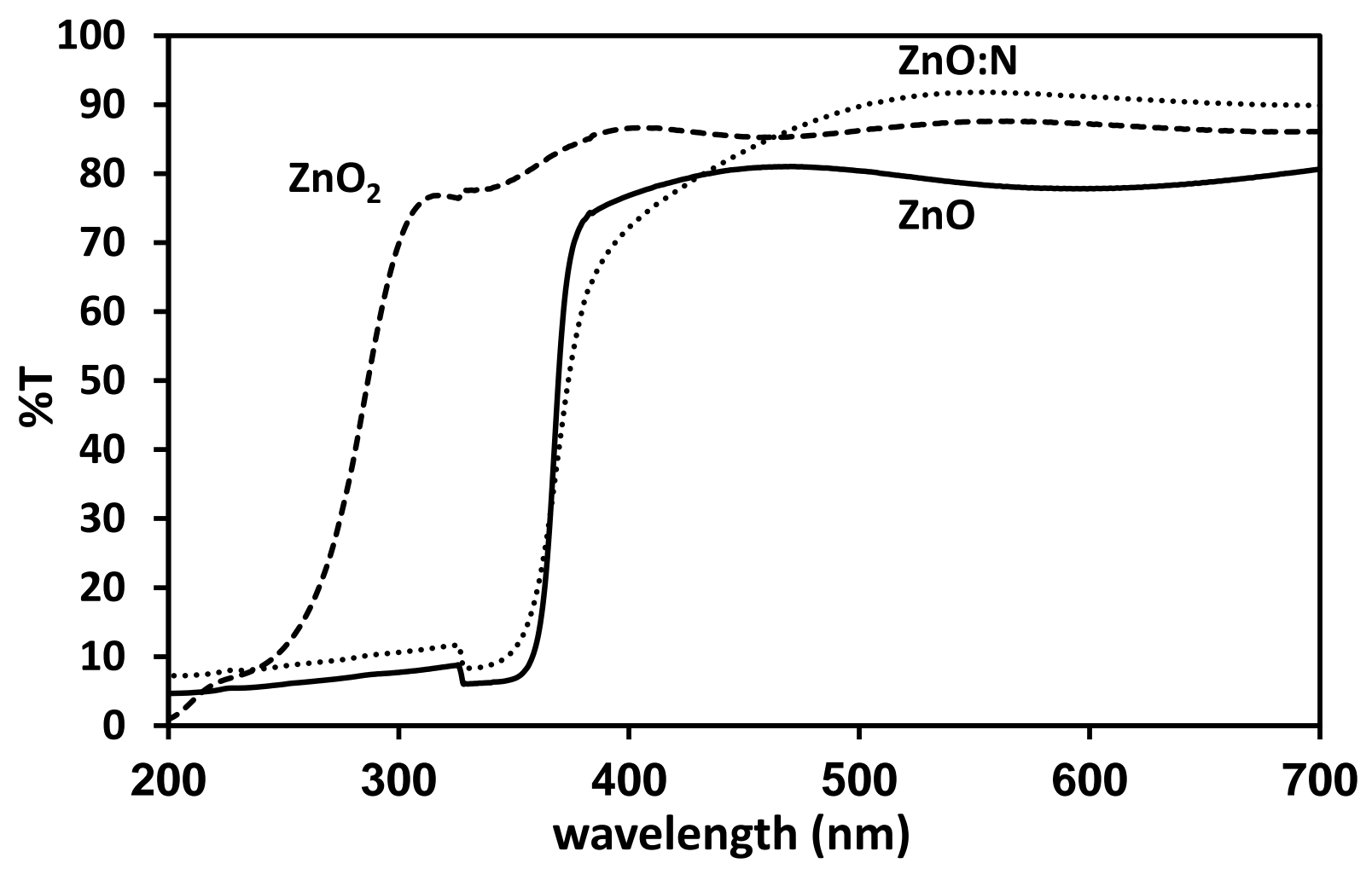

Figure 8: UV-Visible transmittance spectra of $\mathrm{ZnO}, \mathrm{ZnO}_{2}$ and $\mathrm{ZnO}: \mathrm{N}$ thin films on $\mathrm{SiO}_{2}$ substrate. 


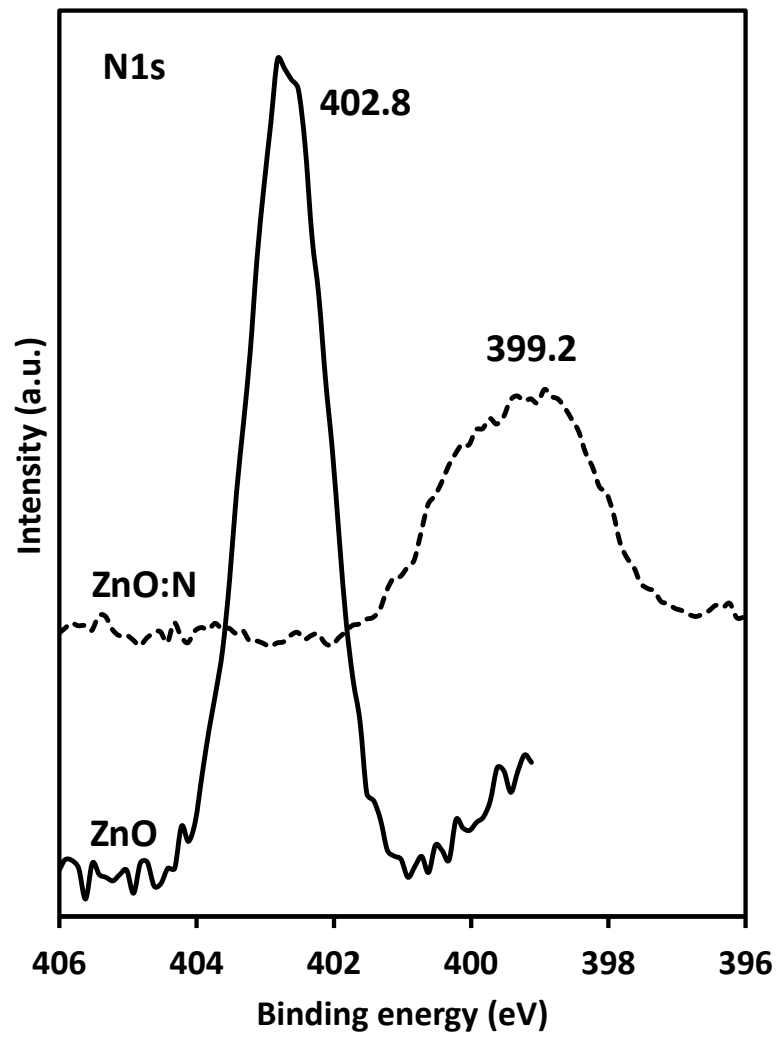

Figure 9: $\mathrm{N}$ 1s XPS spectra of $\mathrm{ZnO}$ and $\mathrm{ZnO}: \mathrm{N}$ thin films. 